\title{
Expression of $\mathbf{K}_{\mathrm{ATP}}$ channels in human cervical cancer: Potential tools for diagnosis and therapy
}

\author{
ALMA YOLANDA VÁZQUEZ-SÁNCHEZ ${ }^{1}$, LUZ MARÍA HINOJOSA² ${ }^{2}$, SARA PARRAGUIRRE-MARTÍNEZ ${ }^{3}$, \\ AARÓN GONZÁLEZ ${ }^{4}$, FLAVIA MORALES ${ }^{5}$, GONZALO MONTALVO $^{6}$, EUNICE VERA ${ }^{1}$, \\ ELISABETH HERNÁNDEZ-GALLEGOS ${ }^{1}$ and JAVIER CAMACHO ${ }^{1}$ \\ ${ }^{1}$ Department of Pharmacology, Center for Research and Advanced Studies of The National Polytechnic Institute, \\ Mexico City 07360; ${ }^{2}$ Service of Dysplasia, Gynecology and Obstetrics, and ${ }^{3}$ Division of Anatomical Pathology, \\ 'Dr Manuel Gea González' Hospital General; ${ }^{4}$ Service of Colposcopy, ${ }^{5}$ Medical Oncology and \\ ${ }^{6}$ Service of Gynecology, Instituto Nacional de Cancerología, Mexico City 14080, Mexico
}

Received January 8, 2017; Accepted October 18, 2017

DOI: $10.3892 / \mathrm{ol} .2018 .8165$

\begin{abstract}
Various ion channels, including ATP-sensitive potassium $\left(\mathrm{K}_{\mathrm{ATP}}\right)$ channels, are expressed in cancer and have been suggested as potential tumor markers and therapeutic targets. $\mathrm{K}_{\text {ATP }}$ channels are composed of at least two types of subunit, an inwardly rectifying $\mathrm{K}^{+}$channel (Kir6.x) and a sulfonylurea receptor (SUR). However, the association between $\mathrm{K}_{\mathrm{ATP}}$ channels and cervical cancer remains elusive. The present study determined that the Kir6.2, SUR1 and SUR2 subunits are expressed in cervical cancer cell lines and/or human biopsies. The potential association of subunit expression with tumor differentiation and invasion was analyzed. The effect of the $\mathrm{K}_{\mathrm{ATP}}$ channel blocker glibenclamide on the proliferation of cervical cancer cell lines was also studied. Five cervical cancer cell lines, two primary cultures of cervical cancer cells, one normal keratinocyte cell line and 74 human biopsies were used in the experiments. The mRNA and protein levels of the Kir6.2 subunit were assessed by reverse transcription-polymerase chain reaction and immunochemistry, respectively. Cell proliferation was evaluated by MTT assay. Kir6.2 subunit overexpression compared with control, was observed in some cervical cancer cell lines and cervical tumor tissues. Additionally, increased $\mathrm{K}_{\mathrm{ATP}}$ channel expression was observed in high-grade, poorly differentiated and invasive human cervical cancer biopsies. Kir6.2 subunit expression was not observed in the majority of the non-cancerous cervical tissues. The effect of the $\mathrm{K}_{\mathrm{ATP}}$ channel blocker glibenclamide on the proliferation of five different cervical cancer cell lines was
\end{abstract}

Correspondence to: Dr Javier Camacho, Department of Pharmacology, Center for Research and Advanced Studies of The National Polytechnic Institute, Avenida Instituto Politécnico Nacional 2508, Mexico City 07360, Mexico

E-mail: fcamacho@cinvestav.mx

Key words: cervical cancer, $\mathrm{K}_{\text {ATP }}$ channels, proliferation, glibenclamide studied, revealing that as Kir6.2 mRNA expression increased, the inhibitory effect of glibenclamide also increased. The results of the present study suggest, for the first time to the best of our knowledge, that the $\mathrm{K}_{\text {ATP }}$ channel subunits, Kir6.2 and SUR2, could potentially represent tools for diagnosing and treating cervical cancer.

\section{Introduction}

Cervical cancer is the fourth most common cancer in women worldwide (1-3). Therefore, finding novel potential targets for diagnosing, prognosing and treating cervical cancer is important. Potassium $\left(\mathrm{K}^{+}\right)$channels are associated with multiple human diseases, including cardiac arrhythmias, diabetes and cancer $(4,5)$. Various $\mathrm{K}^{+}$channels have been proposed as novel targets for cancer therapy (5). The ATP-sensitive potassium $\left(\mathrm{K}_{\text {ATP }}\right)$ channels are heteromultimers composed of at least two types of subunit: An inwardly rectifying $\mathrm{K}^{+}$channel (Kir6.x, which forms the pore of the channel) and a sulfonylurea receptor (SUR) (6). Kir6.2 and SUR1 form the characteristic $\mathrm{K}^{+}$channel in pancreatic $\beta$-cells, thereby coupling the metabolic state of the cell with the electrical activity (7-9). $\mathrm{K}_{\mathrm{ATP}}$ channels are present in numerous types of cells and tissues, including pancreatic $\beta$-cells (10), cardiac muscle (11), smooth muscle (12), skeletal muscle and the brain (13). Sulfonylureas inhibit $\mathrm{K}_{\mathrm{ATP}}$ channels and are used to treat non-insulin dependent diabetes mellitus $(9,14,15)$. In addition, $\mathrm{K}_{\text {АTP }}$ channels represent important therapeutic targets in heart failure (16) and tissue ischemia (17). $\mathrm{K}_{\text {ATP }}$ channels are expressed in multiple types of cancer, including hepatocellular carcinoma (18), human bladder cancer (19), human gastric cancer (20) and glioma (21). Accordingly, $\mathrm{K}_{\mathrm{ATP}}$ channel openers (minoxidil, cromakalim and pinacidil) increase the proliferation of HepG2 liver cancer cells, whereas $\mathrm{K}_{\mathrm{ATP}}$ channel blockers (quinidine and glibenclamide) attenuate cell proliferation (18). Glibenclamide inhibits proliferation and induces apoptosis in various types of cancer, including bladder carcinoma (22), prostate cancer (23) and gastric cancer (20). However, although multiple studies have described the presence of different $\mathrm{K}^{+}$channels in diverse types of human cancer, the association of $\mathrm{K}_{\mathrm{ATP}}$ channels with 
cervical cancer remains elusive. Therefore, the present study assessed whether the Kir6.2, SUR1 and SUR2 subunits are expressed in cervical cancer cell lines and/or human biopsies, and the potential associations between subunit expression and tumor differentiation and invasion were analyzed. The effect of the $\mathrm{K}_{\mathrm{ATP}}$ channel blocker glibenclamide on the proliferation and apoptosis of cervical cancer cell lines was also studied.

\section{Materials and methods}

Cell culture. Two previously established primary cultures of human cervical cancer that were characterized as expressing cytokeratins and the E7 gene from human papilloma virus 16 by immunocytochemistry and PCR, respectively, were used in the current study and cultured as previously described (24). The human cervical cancer cell lines C33A, CaSki, HeLa, INBL and $\mathrm{SiHa}$, and primary epidermal keratinocytes (normal human neonatal foreskin) were obtained from the American Type Culture Collection (Manassas, VA, USA) and cultured according to the supplier's instructions.

Cell viability assays. Cell viability was measured by MTT assay. Cells were seeded at a density of $3.5 \times 10^{3}$ cells into 96 -well plates. After $24 \mathrm{~h}$ of incubation at $37^{\circ} \mathrm{C}$, the cells were cultured with Dulbecco's modified Eagle's medium for cervical cancer cells (cat. no. 12430054; Gibco; Thermo Fisher Scientific, Inc., Waltham MA, USA) and Keratinocyte-SFM (cat. no. 17005042; Gibco; Thermo Fisher Scientific, Inc.) for epidermal keratinocytes)) and various concentrations (40-200 $\mu \mathrm{M})$ of glibenclamide (cat. no. G0639-5G; Sigma-Aldrich; Merck $\mathrm{KGaA}$, Darmstadt, Germany) for different incubation times (24-72 h). Subsequently, MTT tetrazolium salt $(0.5 \mathrm{mg} / \mathrm{ml})$ was added to each well and cells were incubated for a further $4 \mathrm{~h}$. Formazan crystals were then dissolved using SDS, and the absorbance was measured using a Multiskan FC microplate photometer (Thermo Fisher Scientific, Inc.).

Apoptosis assay. HeLa and primary epidermal keratinocytes cells were incubated for $48 \mathrm{~h}$ at $37^{\circ} \mathrm{C}$ in culture medium as previously described, either with or without glibenclamide (100 or $150 \mu \mathrm{M})$ or vehicle (sterile water). Camptothecin (apoptosis inductor, $10 \mathrm{mg} / \mathrm{ml}$ ) and methanol (necrosis inductor, $39.6 \mathrm{mg} / \mathrm{ml}$ ) were used as positive controls. Apoptosis was determined using the Annexin V-FITC kit (Invitrogen; Thermo Fisher Scientific, Inc.) to measure binding to phosphatidylserine and DNA staining by propidium iodide $(1 \mathrm{mg} / \mathrm{ml})$, according to manufacturer's protocol. The experiments were performed using the CyAn ADP flow cytometer (Dako; Agilent Technologies, Inc., Santa Clara, CA, USA). Quadrant analysis was performed using the Summit 4.3 software (Beckman Coulter, Inc., Fullerton, CA).

Human biopsies. Human cervical cancer biopsies were obtained from the Instituto Nacional de Cancerología (Mexico City, Mexico). The protocol was approved by the corresponding Research and Ethics Committees [protocol no. 013/024/GII (CEI/846)] and written informed consent was obtained from all the patients. A total of 74 biopsies were studied and the age of the patients ranged from 25 to 82 years old. The present study only included samples from patients that had not received any anti-cancer therapy and excluded patients that had vaginal infections. Non-cancerous cervical tissues were obtained from hysterectomy patients with benign gynecologic pathology at the Hospital General 'Dr Manuel Gea Gonzalez' (Mexico City, Mexico). The protocol followed the local ethical considerations (protocol no. 11-84-2013) and was approved by the corresponding ethics committee. The non-cancerous cervical tissue group included patients whose cervixes were described as healthy, but excluded patients taking hormones. The tissues were either collected in TRIzol and placed in liquid nitrogen to obtain mRNA, or fixed in formaldehyde $(10 \% \mathrm{w} / \mathrm{v})$ and embedded in paraffin for subsequent immunohistochemical analysis. The samples were classified as adenocarcinoma (AC) or squamous cell carcinoma (SCC), according to the International Federation of Gynecology and Obstetrics (FIGO) staging system (25). A total of 24 cancer biopsies were analyzed for Kir6.2 mRNA expression, and 30 tumor tissues were analyzed for Kir6.2 and SUR protein expression.

Reverse transcription-quantitative polymerase chain reaction (RT-qPCR). RNA was isolated using TRIzol reagent (cat. no. T9424; Sigma-Aldrich; Merck KGaA). The total RNA $(5 \mu \mathrm{g})$ was treated with DNase I (Roche Diagnostics GmbH, Mannheim, Germany; 04716728001) and reverse transcribed using the M-MuLV reverse transcriptase (New England BioLabs, Inc., Ipswich, MA, USA). The temperature and time protocol was as follows: $65^{\circ} \mathrm{C}$ for $5 \mathrm{~min}, 37^{\circ} \mathrm{C}$ for $50 \mathrm{~min}, 70^{\circ} \mathrm{C}$ for $15 \mathrm{~min}$ and $4^{\circ} \mathrm{C}$ for $60 \mathrm{~min}$. When small biopsies were obtained, the total RNA (518 ng) was processed using the Path-ID Multiplex One-Step RT-PCR kit (cat. no. 4388641; Ambion; Thermo Fisher Scientific, Inc.). The expression of Kir6.2 (Hs00265026_s1; Applied Biosystems; Thermo Fisher Scientific, Inc.) was assessed by RT-qPCR using the TaqMan ${ }^{\mathrm{TM}}$ Master-mix based detection system (cat. no. 4304437; Applied Biosystems; Thermo Fisher Scientific, Inc.). The temperature and cycling protocol were as follows: $95^{\circ} \mathrm{C}$ for $10 \mathrm{~min}, 95^{\circ} \mathrm{C}$ for $10 \mathrm{sec}$ and $60^{\circ} \mathrm{C}$ for $1 \mathrm{~min}$. The first two steps were repeated for 40 cycles. Expression of a housekeeping gene, hypoxanthine-guanine phosphoribosyltransferase (cat. no. 4326321E; Applied Biosystems; Thermo Fisher Scientific, Inc.), was used as an internal control. Relative expression levels of the gene of interest were determined by the $2^{-\Delta \Delta \mathrm{Cq}}$ method according to the threshold cycle (26), and 2-3 experimental replicates were performed.

Immunostaining. For immunohistochemistry, serial sections $(5 \mu \mathrm{m})$ were mounted on charged glass slides and deparaffinized. Antigen retrieval and blocking were performed as previously described (24). The slides were then incubated for $2 \mathrm{~h}$ with the primary antibodies, anti-Kir6.2 (1:100; cat. no. NBP1-00900), anti-SUR1 (1:50; cat. no. NBP1-59778) or anti-SUR2 (1:300; cat. no. NBP1-84436; all from Novus Biologicals, LLC, Littleton, $\mathrm{CO}, \mathrm{USA})$, at $4^{\circ} \mathrm{C}$. The antibodies were diluted in ImmunoDetector Protein Blocker/Antibody Diluent (cat. no. 0041; Bio SB, Santa Barbara, CA, USA). Subsequently, the slides were incubated at room temperature with a biotin-conjugated secondary antibody for $15 \mathrm{~min}$, followed by 15 min with horseradish peroxidase (HRP)-conjugated streptavidin polymer (both provided as part of the Mouse/Rabbit ImmunoDetector DAB HRP Brown kit; cat. no. 0005; Bio SB). 


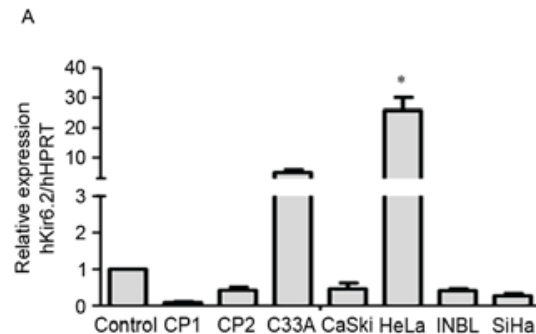

B a
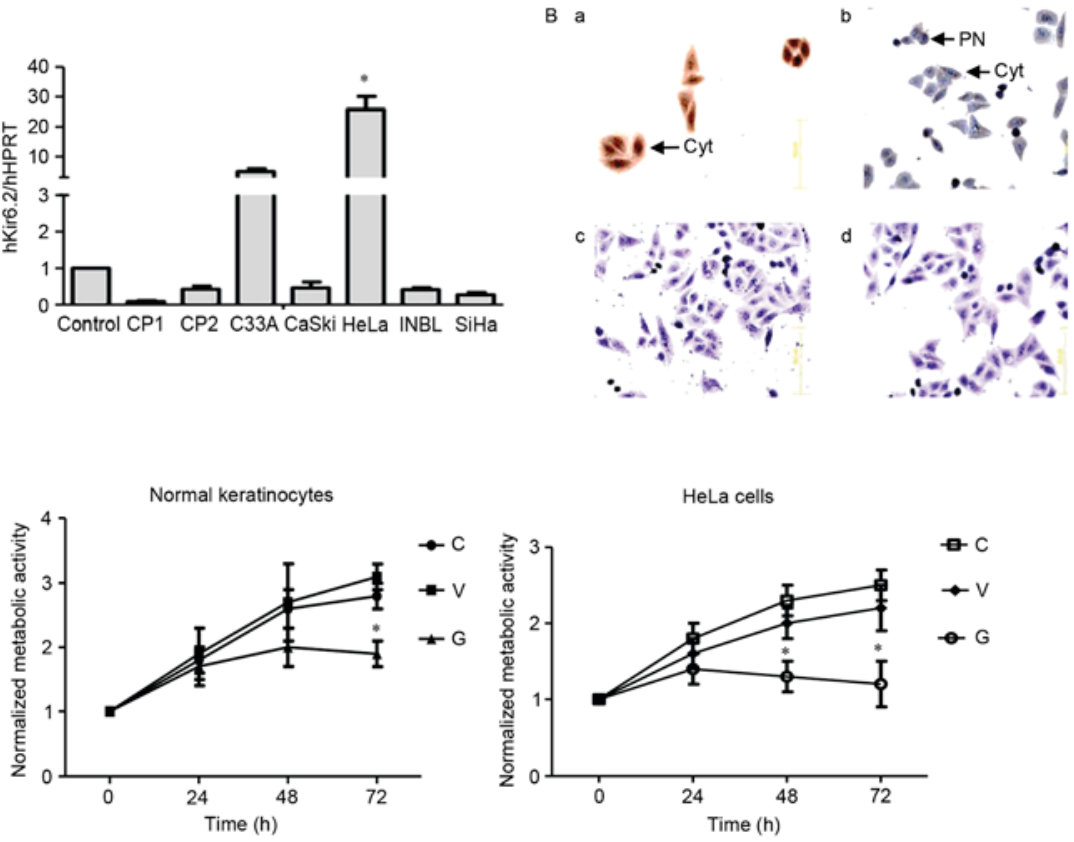
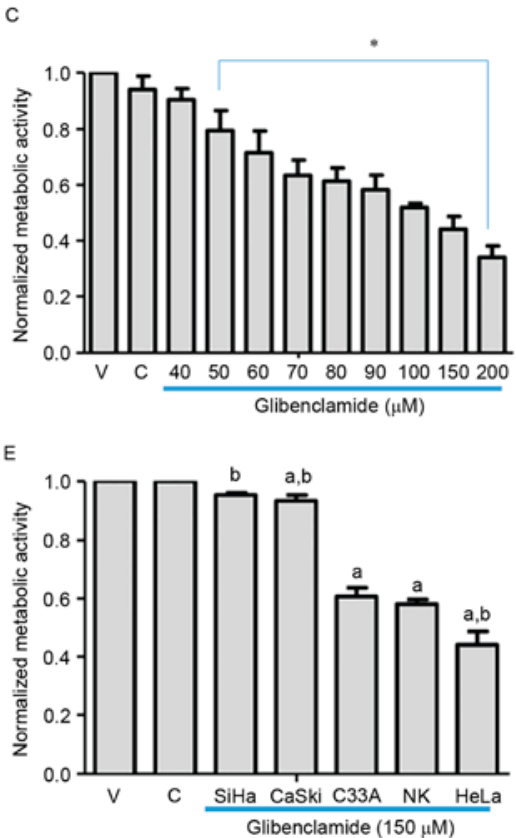

Figure 1. Expression of $\mathrm{K}_{\mathrm{ATP}}$ in cultured cervical cancer cells. (A) Relative mRNA expression of the Kir6.2 subunit in normal keratinocytes (control), primary cultures (CP1 and CP2) and cervical cancer cell lines (CaSki, HeLa, INBL and SiHa). Three different cultures were studied for each cell type. Data are presented as the mean \pm standard deviation ( $\mathrm{P}<0.05$ vs. control). (B) Protein expression of $\mathrm{K}_{\mathrm{ATP}}$ subunits in HeLa cells. Brown immunostaining reveals the presence of the (a) Kir6.2 and (b) SUR2 subunits. Kir6.2 was predominantly localized in the cytoplasm (arrow) while SUR2 was detected in the PN (arrow). No immunostaining was observed in the absence of the primary antibody for either Kir6.2 (c) or SUR2 (d) subunits (magnification, x200). (C-E) Cells were cultured in medium alone ('C'), with sterile water ('V') or with glibenclamide ('G'). Following 48 h of treatment with glibenclamide, HeLa cell viability decreased (C) concentration-dependently and (D) time-dependently at $150 \mu \mathrm{M}$ glibenclamide. The inhibitory effect was increased in HeLa cells compared with normal keratinocytes (D). Data are presented as the mean \pm SEM from three independent experiments ( $\mathrm{P}<0.05$ vs. vehicle). (E) The effect of glibenclamide $(150 \mu \mathrm{M}, 48 \mathrm{~h})$ was increased in cell lines exhibiting increased Kir6.2 mRNA expression. Data are presented as the mean \pm SEM from four independent experiments ( $\mathrm{P}<0.05$ vs. $^{\mathrm{a}}{ }^{\mathrm{v} e h i c l e}$ or ${ }^{\mathrm{b}}$ normal keratinocytes). HPRT, hypoxanthine-guanine phosphoribosyltransferase; NK, normal keratinocytes; $\mathrm{K}_{\mathrm{ATP}}$, ATP-sensitive K-channels; cyt, cytoplasm; PN, perinuclear space; SUR, sulfonylurea receptor; SEM, standard error of the mean; V, vehicle.

The staining reaction was completed in the presence of diaminobenzidine in a buffer reaction solution (\#0005; Bio SB) and washed with distilled water. The slides were counterstained with hematoxylin (Sigma-Aldrich; Merck KGaA) and rinsed with water and ethanol as previously described (24). The slides were mounted with resin (EMD Millipore, Billerica, MA, USA) and observed using an Olympus IX51 light microscope and an Olympus DP70 camera (Olympus Corporation, Tokyo, Japan). Brown immunostaining indicated Kir6.2/SUR1/SUR2 expression.

For immunocytochemistry, cervical cancer cells were mounted on glass coverslips and fixed in ethanol. Subsequently, staining was performed as per the protocol previously described for the tissue samples.

Statistical analysis. Data are presented as the mean \pm SD from three independent experiments with 6-8 replicates for cell proliferation assays and 2-3 replicates for PCR studies. Data were analyzed by a Student's t-test or by an analysis of variance followed by a Tukey-Kramer post hoc test using the GraphPad Prism software version 5.0 (GraphPad Software, Inc., La Jolla, CA, USA). $\mathrm{P}<0.05$ was considered to indicate a statistically significant difference.

\section{Results}

Differential expression of Kir6.2 $\mathrm{mRNA}$ and protein in cervical cancer cell lines. Kir6.2 subunit expression was assessed in two primary cultures of cervical cancer (PC1 and PC2) and five human cervical cancer cell lines (C33A, CaSki, HeLa, INBL and SiHa). The expression of Kir6.2 subunit mRNA was evaluated by RT-qPCR and normalized relative to $\mathrm{K}_{\mathrm{ATP}}$ channel expression in normal primary epidermal keratinocytes. $\mathrm{K}_{\mathrm{ATP}}$ channel expression was present in each of the cell lines and primary cultures (Fig. 1A). However, the only statistically significant difference $(\mathrm{P}<0.05)$ compared with normal keratinocytes was $\mathrm{K}_{\mathrm{ATP}}$ channel overexpression in HeLa cells. Therefore, HeLa cells were used in further analyses of $\mathrm{K}_{\mathrm{ATP}}$ channel protein expression. Fig. 1B depicts the protein expression of the Kir6.2 and SUR2 subunits in HeLa cells. Human cerebral cortex and testis samples were used as positive controls for Kir6.2 and SUR2 protein expression, respectively (data not shown). SUR1 protein expression was not detected (data not shown), whereas the SUR2 subunit was positively stained. These results suggested that HeLa cells express $\mathrm{K}_{\text {ATP }}$ channels composed of Kir6.2 and SUR2 subunits, and that these channels may serve a function in cervical carcinogenesis.

Glibenclamide decreases cervical cancer and normal keratinocyte cell proliferation. The effect of glibenclamide, a $\mathrm{K}_{\mathrm{ATP}}$ channel inhibitor, on HeLa cell proliferation was investigated by assaying the metabolic activity. The HeLa cells were incubated with various glibenclamide concentrations $(40-200 \mu \mathrm{M})$ for $48 \mathrm{~h}$, which resulted in a concentration- and time-dependent decrease in cell viability of $>60 \%$ at the highest concentration 
compared with the vehicle-treated cells (Fig. 1C and D). By contrast, glibenclamide $(150 \mu \mathrm{M})$ decreased the proliferation of normal keratinocytes by $30 \%$ (Fig. 1D). The present study also studied the effect of glibenclamide on other cervical cancer cell lines that displayed varying mRNA expression levels of the Kir6.2 subunit. The results revealed that as the Kir6.2 mRNA expression levels increased, the inhibitory effect of glibenclamide also increased (Fig. 1E). Glibenclamide did not affect apoptosis (data not shown).

$K_{A T P}$ channel mRNA expression in human biopsies and its potential association with tumor differentiation and invasion. Kir6.2 subunit mRNA expression was assessed in 24 cervical cancer samples (22 SCC and 2 AC biopsies). The samples were classified as cervical cancer of FIGO stage I (4 samples from stage IA and 2 samples from stage IB), II (1 sample from stage IIA and 5 samples from stage IIB), III (7 samples from stage IIIB) or IV (3 samples from stage IVB), and included $1 \mathrm{AC}$ in situ and 1 invasive AC. The mRNA expression of 10 non-cancerous cervical biopsies (controls) from other patients was normalized to 1 and used for comparison. Increased Kir6.2 mRNA expression was detected in the stage IV SCC biopsies (Fig. 2A), with some of these samples exhibiting mRNA levels $\leq 60 x$ those of the controls. Differential Kir6.2 mRNA expression was also observed in invasive tumors; compared with non-invasive tumors or non-cancerous biopsies (control group; expression value normalized to 1), some of the invasive tumors displayed $>50 \mathrm{x}$ the Kir6.2 mRNA expression (Fig. 2B). Non-invasive tumors were considered to be those where the invasive component was delimited to microscopic foci of only a few microns in length and depth, as observed in in situ carcinoma biopsies (microinvasive tumors, 4 samples from cervical cancer FIGO stage IAI and $1 \mathrm{AC}$ in situ). The samples were also divided according to their differentiation grade into well, moderately or poorly differentiated groups. Increased Kir6.2 subunit expression was observed in samples from the moderate and poor differentiation grades and certain biopsies from these groups displayed $\leq 50 \mathrm{x}$ Kir6.2 mRNA levels compared with the controls (Fig. 2C). The present study also analyzed the potential association between Kir6.2 and lymphovascular space invasion. In total, 7 samples exhibited lymphovascular space invasion and $100 \%$ of these samples displayed increased Kir6.2 mRNA expression. However, 13/23 (56.6\%) samples exhibiting no lymphovascular space invasion also displayed increased Kir6.2 mRNA expression. No significant association was identified between lymphovascular invasion and mRNA channel expression.

Kir6.2 and SUR protein expression in human cervical tissues. The present study determined the protein expression levels of the Kir6.2 and SUR2 subunits in human cervical biopsies by performing immunohistochemical analysis on 30 cervical cancer tissues (24 SCCs and 6 ACs) and 10 non-cancerous cervical tissues (controls). All of these samples were obtained from different patients from those that participated in the mRNA studies. Kir6.2 subunit immunostaining was not observed in the majority (9/10) of the non-cancerous cervical tissues (Fig. 3A), while 1 sample exhibited a weak signal. Similarly, SUR2 expression was not observed in any of these non-cancerous cervical tissues (Fig. 3B). By contrast, 10/30 cervical cancer
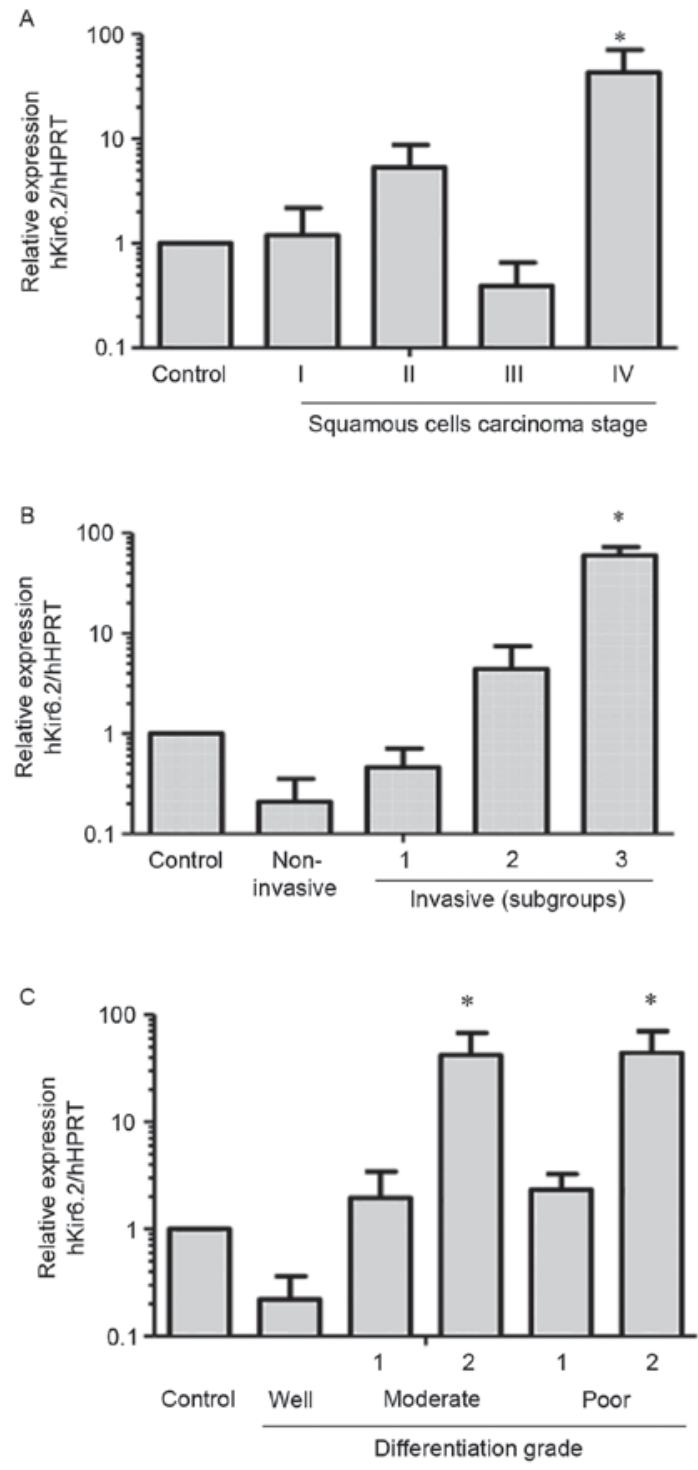

Figure 2. Kir6.2 mRNA expression in human cervical biopsies. The values were normalized relative to the Kir6.2 expression of 10 non-cancerous cervical tissue samples (control). (A) Kir6.2 subunit mRNA expression in samples from different clinical stages of squamous cell carcinoma: Stage I $(n=6)$, stage II $(n=6)$, stage III $(n=7)$ and stage IV $(n=3)$. Samples from stage IV exhibited increased expression. ${ }^{*} \mathrm{P}<0.05$ vs. control. (B) Samples were classified as non-invasive $(n=5)$, invasive $1(n=7)$, invasive $2(n=12)$ and invasive $3(n=4)$. The relative mRNA expression of the Kir6.2 subunit was increased in multiple invasive tissues. ${ }^{*} \mathrm{P}<0.05$ vs. control and non-invasive groups. (C) The biopsies were grouped according to their differentiation grade into well, moderately or poorly differentiated, and the moderate and poor groups were each divided into two subgroups based on their relative expression patterns: Well $(n=4)$; moderate-1 $(n=13)$; moderate- $2(n=3)$; poor-1 $(n=4)$; poor- $2(n=3){ }^{*} \mathrm{P}<0.05$ vs. control, well, moderate- 1 and poor- 1 . HPRT, hypoxanthine-guanine phosphoribosyltransferase; SD, standard deviation.

samples revealed strong Kir6.2 staining (Fig. 3A). The positive biopsies corresponded to samples classified as cervical cancer FIGO stage I (1 sample from stage IA and 1 sample from stage IB), stage II (2 samples from stage IIB), III (2 samples from stage IIIB) and stage IV (1 sample from stage IVA and 2 samples from stage IVB), and 1 AC from stage IB. Stromal cells in the tumor tissues also exhibited Kir6.2 staining. SUR2 subunit expression was detected in 4 cancer tissues (Fig. 3B). Two samples in the immunochemical analysis were obtained from patients with lymphovascular space invasion, both 
A

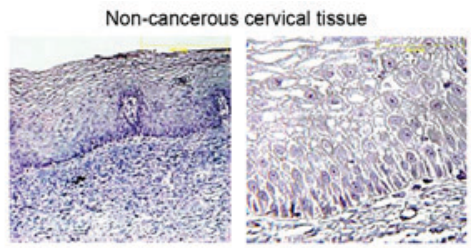

Kir6.2

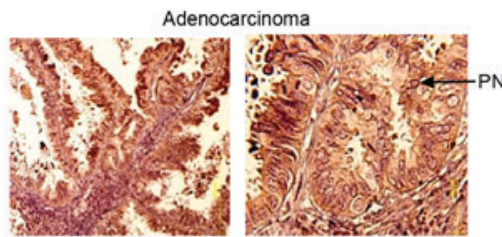

B

SUR2

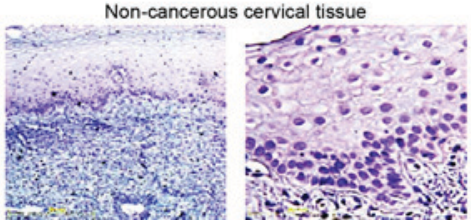

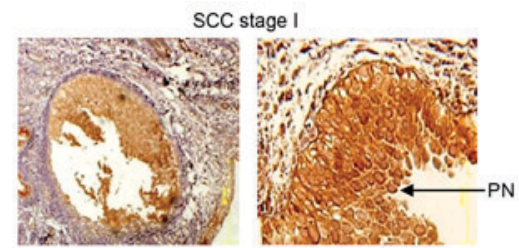

SCC stage II

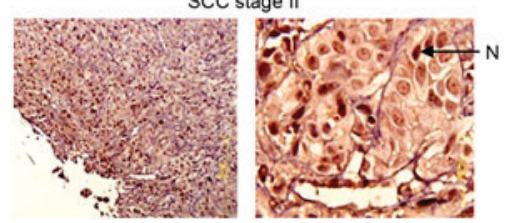

Adenocarcinoma

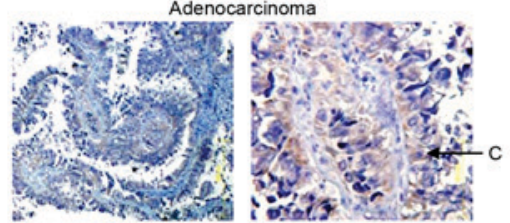

SCC stage III

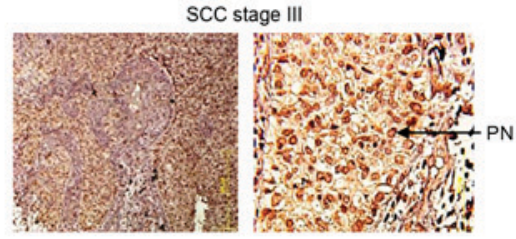

SCC stage IV

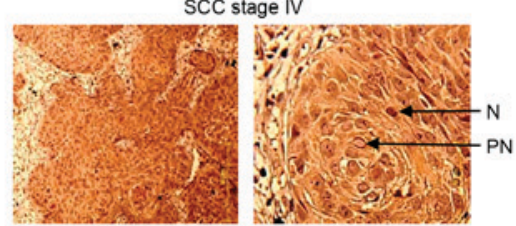

SCC

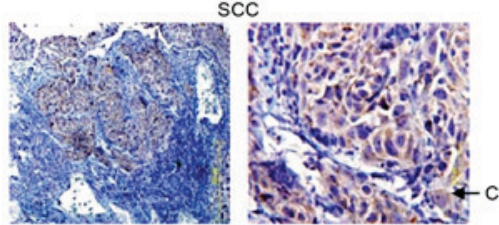

Figure 3. Increased protein expression of ATP-sensitive $\mathrm{K}^{+}$channels in human cervical cancer tissues. Brown immunostaining indicated the presence of the proteins. Representative serial sections from non-cancerous, adenocarcinoma or SCC cervical biopsies are shown. (A) Kir6.2 subunit expression. Strong channel expression was observed in the cancer tissues; no expression was detected in the non-cancerous sample. Kir6.2 was predominantly localized in the nucleus and the perinuclear space. (B) SUR2 subunit expression. The protein was predominantly localized in the cytoplasm of the cancer samples. No staining was observed in the non-cancerous cervical tissue. Images at x100 magnification (left) and x400 magnification (right) are shown for each tissue type. SCC, squamous cell carcinoma; N, nucleus; PN, perinuclear space; SUR, sulfonylurea receptor; C, cytoplasm.

of which displayed increased Kir6.2 protein expression in comparison with controls (data not shown).

\section{Discussion}

The present study demonstrated, for the first time to the best of our knowledge, the presence of Kir6.2 subunit expression in cervical cancer cell lines and human biopsies. The differential Kir6.2 subunit expression observed in cervical cancer cell lines and human cervical biopsies reflect the heterogeneity among cervical tumors. The $\mathrm{K}_{\mathrm{ATP}}$ channel blocker glibenclamide decreased cell proliferation in HeLa cells more than that in the control cells (normal keratinocytes). Although the inhibitory function of glibenclamide may be explained by its ability to block $\mathrm{K}_{\mathrm{ATP}}$ channels (9) in cervical cancer cells, it cannot be ruled out that other proteins may also be involved. For example, glibenclamide also inhibits other ATP-binding cassette transporters (27-36). Peng et al (37) suggested that increased cystic fibrosis transmembrane conductance regulator expression is associated with cervical cancer progression and a poor prognosis. Since glibenclamide did not induce apoptosis, its anti-proliferative effects may be associated with cell cycle arrest in the G1-S phase, as reported for human bladder (HTB-9) and breast (MDA-MB-231) carcinoma cells (22-38). While further studies are required to reveal the molecular mechanism of the anti-proliferative effects of glibenclamide, the results of the present study suggested that this drug could represent a potential therapy for patients with cervical cancer overexpressing $\mathrm{K}_{\mathrm{ATP}}$ channels. Cervical cancer incidence in diabetic patients taking glibenclamide requires further investigation. A limitation of the present study was that the presence of diabetes mellitus was not an exclusion criterion.

Human cervical biopsies also displayed differential expression of Kir6.2 subunit mRNA. Increased mRNA levels were observed in samples from patients with stage IV SCC in comparison with control and low stages samples. Increased mRNA expression was also identified in certain invasive or poorly differentiated carcinoma tissues in comparison with non-invasive or well-differentiated samples. Strong Kir6.2 protein expression was observed in $33 \%$ of the cancer samples, while the non-cancerous cervical tissues displayed weak immunostaining in only $1 / 10$ samples and no expression of the SUR2 subunit. While Kir6.2 protein expression was observed in 10/30 cancer tissues, SUR2 subunit expression was detected in 4 cancer tissues. This could be because the SUR2 gene encodes different isoforms and splice variants $(7,9)$, some of which may not be recognized by the antibody used. Although the present study did not find an association between Kir6.2 expression and lymphovascular space invasion, all of the samples exhibiting lymphovascular space invasion displayed increased Kir6.2 mRNA and/or protein expression in comparison with control samples.

Various $\mathrm{K}^{+}$channels have been demonstrated to contribute to cancer cell invasion and metastasis in other types of cancer, including Kv1.3 in melanoma (39-52). Further studies are required to elucidate the function of $\mathrm{K}_{\mathrm{ATP}}$ channels in cervical cancer progression and malignancy and the potential associated mechanism. In addition, future clinical studies should aim to increase the number of human biopsies analyzed. A potential limitation of the present study is that hysterectomy samples may undergo hypoxia due to the ligation of the descending uterine vessels during surgery. In addition, although the control samples were reported as healthy, future studies should aim to include normal cervical biopsies obtained without hysterectomy.

Further studies of the association between Kir6.2 expression and overall survival in patients with cervical cancer are required. In addition, the effect of glibenclamide in in vivo 
cervical cancer models and in patient-derived xenografts should also be investigated. The present study observed increased $\mathrm{K}_{\text {ATP }}$ channel expression in invasive cervical cancer samples and in those that were poorly differentiated and of an advanced stage in comparison with the control and some samples from the non-invasive or low-stage groups. Furthermore, the present study revealed a potential function for these channels in cervical cancer cell proliferation. The results of the present study suggest that $\mathrm{K}_{\mathrm{ATP}}$ channels may represent potential tools for cervical cancer diagnosis and therapy. Since glibenclamide inhibited the proliferation of cervical cancer cells displaying increased Kir6.2 mRNA expression, $\mathrm{K}_{\mathrm{ATP}}$ channels may be a novel therapeutic target in patients with cervical cancer overexpressing this protein.

\section{References}

1. Ferlay J, Soerjomataram I, Dikshit R, Eser S, Mathers C, Rebelo M, Parkin DM, Forman D and Bray F: Cancer incidence and mortality worldwide: Sources, methods and major patterns in GLOBOCAN 2012. Int J Cancer 136: E359-E386, 2015.

2. Moore DH: Cervical cancer. Obstet Gynecol 107: 1152-1161, 2006.

3. Cadron I, Van Gorp T, Amant F, Leunen K, Neven P and Vergote I: Chemotherapy for recurrent cervical cancer. Gynecol Oncol 107(1 Suppl 1): S113-S118, 2007.

4. Dubois JM and Rouzaire-Dubois B: Role of potassium channels in mitogenesis. Prog Biophys Mol Biol 59: 1-21, 1993.

5. Pardo LA and Stühmer W: The roles of $\mathrm{K}(+)$ channels in cancer. Nat Rev Cancer 14: 39-48, 2014.

6. Clement JP IV, Kunjilwar K, Gonzalez G, Schwanstecher M, Panten U, Aguilar-Bryan L and Bryan J: Association and stoichiometry of K(ATP) channel subunits. Neuron 18: 827-838, 1997.

7. Babenko AP, Aguilar-Bryan L and Bryan J: A view of sur/KIR6.X, KATP channels. Annu Rev Physiol 60: 667-687, 1998.

8. Inagaki N, Gonoi T, Clement JP, Wang CZ, Aguilar-Bryan L, Bryan J and Seino S: A family of sulfonylurea receptors determines the pharmacological properties of ATP-sensitive $\mathrm{K}^{+}$channels. Neuron 16: 1011-1017, 1996.

9. Aguilar-Bryan L and Bryan J: Molecular biology of adenosine triphosphate-sensitive potassium channels. Endocr Rev 20: 101-135, 1999.

10. Aguilar-Bryan L, Nichols CG, Wechsler SW, Clement JP IV, Boyd AE III, González G, Herrera-Sosa H, Nguy K, Bryan J and Nelson DA: Cloning of the beta cell high-affinity sulfonylurea receptor: A regulator of insulin secretion. Science 268: 423-426, 1995.

11. Noma A: ATP-regulated $\mathrm{K}^{+}$channels in cardiac muscle. Nature 305: 147-148, 1983.

12. Quayle JM, Nelson MT and Standen NB: ATP-sensitive and inwardly rectifying potassium channels in smooth muscle. Physiol Rev 77: 1165-1232, 1997.

13. Sakura H, Ammälä C, Smith PA, Gribble FM and Ashcroft FM: Cloning and functional expression of the cDNA encoding a novel ATP-sensitive potassium channel subunit expressed in pancreatic beta-cells, brain, heart and skeletal muscle. FEBS Lett 377 338-344, 1995 .

14. Trube G, Rorsman P and Ohno-Shosaku T: Opposite effects of tolbutamide and diazoxide on the ATP-dependent $\mathrm{K}^{+}$channel in mouse pancreatic beta-cells. Pflugers Arch 407: 493-499, 1986.

15. Sturgess NC, Ashford ML, Cook DL and Hales CN: The sulphonylurea receptor may be an ATP-sensitive potassium channel Lancet 2: 474-475, 1985.

16. Kasikcioglu HA and Cam N: A review of levosimendan in the treatment of heart failure. Vasc Health Risk Manag 2: 389-400, 2006.

17. Downey JM and Cohen MV: Do mitochondrial KATP channels serve as triggers rather than end-effectors of ischemic preconditioning's protection? Basic Res Cardiol 95: 272-274, 2000.

18. Malhi H, Irani AN, Rajvanshi P, Suadicani SO, Spray DC, McDonald TV and Gupta S: KATP channels regulate mitogenically induced proliferation in primary rat hepatocytes and human liver cell lines. Implications for liver growth control and potential therapeutic targeting. J Biol Chem 275: 26050-26057, 2000.
19. Monen SH, Schmidt PH and Wondergem R: Membrane potassium channels and human bladder tumor cells. I. Electrical properties. J Membr Biol 161: 247-256, 1998.

20. Qian X, Li J, Ding J, Wang Z, Duan L and Hu G: Glibenclamide exerts an antitumor activity through reactive oxygen species-c-jun NH2-terminal kinase pathway in human gastric cancer cell line MGC-803. Biochem Pharmacol 76: 1705-1715, 2008.

21. Huang L, Li B, Li W, Guo H and Zou F: ATP-sensitive potassium channels control glioma cells proliferation by regulating ERK activity. Carcinogenesis 30: 737-744, 2009.

22. Wondergem R, Cregan M, Strickler L, Miller R and Suttles J: Membrane potassium channels and human bladder tumor cells: II. Growth properties. J Membr Biol 161: 257-262, 1998.

23. Abdul M and Hoosein N: Expression and activity of potassium ion channels in human prostate cancer. Cancer Lett 186: 99-105, 2002.

24. Farias LM, Ocaña DB, Díaz L, Larrea F, Avila-Chávez E, Cadena A, Hinojosa LM, Lara G, Villanueva LA, Vargas C, et al: Ether a go-go potassium channels as human cervical cancer markers. Cancer Res 64: 6996-7001, 2004.

25. Pecorelli S: Revised FIGO staging for carcinoma of the vulva, cervix, and endometrium. Int J Gynaecol Obstet 105: 103-104, 2009.

26. Livak KJ and Schmittgen TD: Analysis of relative gene expression data using real-time quantitative PCR and the 2(-Delta Delta C(T)) method. Methods 25: 402-408, 2001.

27. Payen L, Delugin L, Courtois A, Trinquart Y, Guillouzo A and Fardel O: The sulphonylurea glibenclamide inhibits multidrug resistance protein (MRP1) activity in human lung cancer cells Br J Pharmacol 132: 778-784, 2001.

28. Borst P, Evers R, Kool M and Wijnholds J: The multidrug resistance protein family. Biochim Biophys Acta 1461: 347-357, 1999.

29. Lautier D, Canitrot Y, Deeley RG and Cole SP: Multidrug resistance mediated by the multidrug resistance protein (MRP) gene. Biochem Pharmacol 52: 967-977, 1996.

30. Sheppard DN and Robinson KA: Mechanism of glibenclamide inhibition of cystic fibrosis transmembrane conductance regulator Cl- channels expressed in a murine cell line. J Physiol 503: 333-346, 1997.

31. Kim JA, Kang YS, Lee SH, Lee EH, Yoo BH and Lee YS: Glibenclamide induces apoptosis through inhibition of cystic fibrosis transmembrane conductance regulator (CFTR) $\mathrm{Cl}(-)$ channels and intracellular $\mathrm{Ca}(2+)$ release in HepG2 human hepatoblastoma cells. Biochem Biophys Res Commun 261: 682-688, 1999.

32. Sheppard DN and Welsh MJ: Effect of ATP-sensitive $\mathrm{K}^{+}$channel regulators on cystic fibrosis transmembrane conductance regulator chloride currents. J Gen Physiol 100: 573-591, 1992.

33. Gerloff T, Stieger B, Hagenbuch B, Madon J, Landmann L, Roth J, Hofmann AF and Meier PJ: The sister of P-glycoprotein represents the canalicular bile salt export pump of mammalian liver. J Biol Chem 273: 10046-10050, 1998.

34. Stieger B, Fattinger K, Madon J, Kullak-Ublick GA and Meier PJ Drug- and estrogen-induced cholestasis through inhibition of the hepatocellular bile salt export pump (Bsep) of rat liver. Gastroenterology 118: 422-430, 2000.

35. Ambudkar SV, Dey S, Hrycyna CA, Ramachandra M, Pastan I and Gottesman MM: Biochemical, cellular, and pharmacological aspects of the multidrug transporter. Annu Rev Pharmacol Toxicol 39: 361-398, 1999 .

36. Golstein PE, Boom A, van Geffel J, Jacobs P, Masereel B and Beauwens R: P-glycoprotein inhibition by glibenclamide and related compounds. Pflugers Arch 437: 652-660, 1999.

37. Peng X, Wu Z, Yu L, Li J, Xu W, Chan HC, Zhang Y and Hu L: Overexpression of cystic fibrosis transmembrane conductance regulator (CFTR) is associated with human cervical cancer malignancy, progression and prognosis. Gynecol Oncol 125: 470-476, 2012.

38. Núñez M, Medina V, Cricco G, Croci M, Cocca C, Rivera E, Bergoc R and Martín G: Glibenclamide inhibits cell growth by inducing G0/G1 arrest in the human breast cancer cell line MDA-MB-231. BMC Pharmacol Toxicol 14: 6, 2013.

39. Artym VV and Petty HR: Molecular proximity of Kv1.3 voltage-gated potassium channels and beta(1)-integrins on the plasma membrane of melanoma cells: Effects of cell adherence and channel blockers. J Gen Physiol 120: 29-37, 2002.

40. Agarwal JR, Griesinger F, Stühmer W and Pardo LA: The potassium channel Ether à go-go is a novel prognostic factor with functional relevance in acute myeloid leukemia. Mol Cancer 9: 18,2010 . 
41. Afrasiabi E, Hietamäki M, Viitanen T, Sukumaran P, Bergelin N and Törnquist $\mathrm{K}$ : Expression and significance of HERG (KCNH2) potassium channels in the regulation of MDA-MB-435S melanoma cell proliferation and migration. Cell Signal 22: 57-64, 2010.

42. Pillozzi S, Brizzi MF, Bernabei PA, Bartolozzi B, Caporale R, Basile V, Boddi V, Pegoraro L, Becchetti A and Arcangeli A: VEGFR-1 (FLT-1), beta1 integrin, and hERG K+ channel for a macromolecular signaling complex in acute myeloid leukemia: Role in cell migration and clinical outcome. Blood 110 1238-1250, 2007.

43. Cherubini A, Hofmann G, Pillozzi S, Guasti L, Crociani O, Cilia E, Di Stefano P, Degani S, Balzi M, Olivotto M, et al: Human ether-a-go-go-related gene 1 channels are physically linked to beta1 integrins and modulate adhesion-dependent signaling. Mol Biol Cell 16: 2972-2983, 2005.

44. Lastraioli E, Guasti L, Crociani O, Polvani S, Hofmann G, Witchel H, Bencini L, Calistri M, Messerini L, Scatizzi M, et al: herg1 gene and HERG1 protein are overexpressed in colorectal cancers and regulate cell invasion of tumor cells. Cancer Res 64 606-611, 2004

45. Guo Z, Liu J, Zhang L, Su B, Xing Y, He Q, Ci W, Li X and Zhou L: KCNJ1 inhibits tumor proliferation and metastasis and is a prognostic factor in clear cell renal cell carcinoma. Tumour Biol 36: 1251-1259, 2015.

46. Veeravalli KK, Ponnala S, Chetty C, Tsung AJ, Gujrati M and Rao JS: Integrin $\alpha 931$-mediated cell migration in glioblastoma via SSAT and Kir4.2 potassium channel pathway. Cell Signal 24 272-281, 2012.
47. Kraft R, Krause P, Jung S, Basrai D, Liebmann L, Bolz J and Patt S: BK channel openers inhibit migration of human glioma cells. Pflugers Arch 446: 248-255, 2003.

48. Weaver AK, Bomben VC and Sontheimer H: Expression and function of calcium-activated potassium channels in human glioma cells. Glia 54: 223-233, 2006.

49. Sciaccaluga M, Fioretti B, Catacuzzeno L, Pagani F, Bertollini C, Rosito M, Catalano M, D'Alessandro G, Santoro A, Cantore G, et al: CXCL12-induced glioblastoma cell migration requires intermediate conductance $\mathrm{Ca}^{2+}$-activated $\mathrm{K}^{+}$channel activity. Am J Physiol Cell Physiol 299: C175-C184, 2010.

50. Cuddapah VA, Turner KL, Seifert S and Sontheimer H: Bradykinin-induced chemotaxis of human gliomas requires the activation of KCa3.1 and ClC-3. J Neurosci 33: 1427-1440, 2013.

51. Chantôme A, Potier-Cartereau M, Clarysse L, Fromont G, Marionneau-Lambot S, Guéguinou M, Pagès JC, Collin C, Oullier T, Girault A, et al: Pivotal role of the lipid Raft SK3-Orail complex in human cancer cell migration and bone metastases. Cancer Res 73: 4852-4861, 2013.

52. Liu X, Chang Y, Reinhart PH, Sontheimer H and Chang Y: Cloning and characterization of glioma BK, a Novel BK Channel isoform highly expressed in human glioma cells. J Neurosci 22: $1840-1849,2002$

(i) $(9$ This work is licensed under a Creative Commons Attribution-NonCommercial-NoDerivatives 4.0 International (CC BY-NC-ND 4.0) License. 